\title{
Gayo Language
}

National Cancer Institute

\section{Source}

National Cancer Institute. Gayo Language. NCI Thesaurus. Code C153927.

An Austronesian language spoken in the mountainous region of Aceh, Central Aceh, Bener Meriah, and Gayo Lues regencies of Indonesia. 